\title{
Distribution of overwintering Calanus in the North Norwegian Sea
}

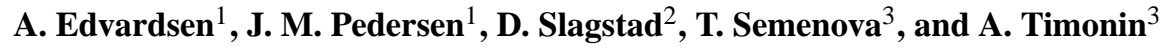 \\ ${ }^{1}$ Department of Aquatic BioSciences, Norwegian College of Fishery Science, University of Troms $\varnothing$, 9037 Troms $\varnothing$, Norway \\ ${ }^{2}$ SINTEF Fisheries and Aquaculture, 7465 Trondheim, Norway \\ ${ }^{3}$ P. P. Shirsov Institute of Oceanology, Russian Academy of Science, Krasikova St. 23, Moscow, 117218 , Russia
}

Received: 16 January 2006 - Published in Ocean Sci. Discuss.: 31 March 2006

Revised: 16 June 2006 - Accepted: 21 June 2006 - Published: 25 July 2006

\begin{abstract}
During winter 2003 and 2004, zooplankton and hydrographic data were collected in the northern parts of the Norwegian Sea $\left(68-72^{\circ} \mathrm{N}, 8-17^{\circ} \mathrm{E}\right)$ west of the Norwegian shelf break at depths down to $1800 \mathrm{~m}$. The results cover both inter and intra annual changes of hydrography and distribution of Calanus spp. For the whole survey area, average seawater temperature down to $1000 \mathrm{~m}$ was higher in 2004 than in the same period in 2003. For the upper $500 \mathrm{~m}$ the difference was ca. $1^{\circ}$ C. Calanus finmarchicus dominated at ca. $75 \%$ of the total copepod abundance. Typical abundance of $C$. finmarchicus in the survey area was $30000-40000 \mathrm{~m}^{-2}$. C. hyperboreus was found deeper than C. finmarchicus while other copepods were found at the depth of $C$. finmarchicus or shallower. From January to February 2004, the peak of abundance of $C$. finmarchicus and $C$. hyperboreus shifted approximately $300 \mathrm{~m}$ upwards indicating that ascent from overwintering depth took place at a speed of $10 \mathrm{~m} \mathrm{~d}^{-1}$ during this period. In general, high abundance of copepods was found adjacent to the shelf slope while oceanic areas had low and intermediate abundance. In the southern part of the survey area, location of high and low copepod abundance shifted both between and within years. In the northern part of the survey area where the shelf slope is less steep, copepods was present at intermediate and high abundance during all surveys.
\end{abstract}

\section{Introduction}

The essential role of copepods in the marine food web and its potential sensitivity to changes in the physical properties of the the sea has prompted an enhanced research focus on these organisms. In the North Atlantic, Calanus finmarchicus is by biomass the dominating species (Planque and Batten, 2000),

Correspondence to: A. Edvardsen

(edvard@nfh.uit.no) making it a prime target for several recent research projects (e.g. ICOS Heath et al., 1999 and TASC Tande and Miller, 2000). Yet, compared to the pool of data available from the productive period during spring and summer, information during the overwintering phase is rudimentary. The interactions between biological processes related to overwintering (e.g. active and passive vertical movement, metabolism) and physical processes of the ocean can act as a strong moderator on the recruitment and distribution during spring and summer. In addition, these physical-biological interactions might represent a prerequisite for persistence within populations of Calanus in the North Atlantic (Heath et al., 2004; Irigoien, 2004).

At higher latitudes Calanus typically enters a state of diapause during autumn after descending to depths below $600 \mathrm{~m}$ (Østvedt, 1955; Hirche, 1991, 1996). The winter months is spent living on accumulated lipid reserves at low respiration rates (Hirche, 1996). Enhanced probability of survival due to low temperatures and reduced exposure to predators and parasites are considered to be the main reason for escaping surface waters during winter (Krause and Radach, 1989; Kaartvedt, 1996). In spring the overwintering population ascends to surface waters where it matures and spawns. In the southern part of the Norwegian Sea the depth layers occupied by the species Calanus finmarchicus corresponds to the upper parts of Norwegian Sea deep water, a polar water mass found below and flowing in the opposite direction to the poleward North Atlantic Current running along the continental shelf slope (Heath et al., 1999). During diapause, animals are transported southwards from the Norwegian Sea through the Faroe-Shetland Channel into the Atlantic and then carried back again when ascending in spring (Backhaus et al., 1994; Bryant et al., 1998; Heath et al., 1999).

From a 15 year data series on abundance of $C$. finmarchicus during the spring and early summer, Tande et al. (2000) showed that the abundance co-varied throughout the entire region from the NE Norwegian Sea to the eastern part of the

Published by Copernicus GmbH on behalf of the European Geosciences Union. 
Table 1. Cruise names, sampling periods, numbers of stations and instruments used during the surveys in 2003 and 2004.

\begin{tabular}{lccc}
\hline Cruise & Period & Stations & Instruments \\
\hline PCB7 & 19 Jan-1 Feb 2003 & 54 & CTD, Multinet \\
PCB9 & 11-25 Jan 2004 & 50 & CTD, Multinet \\
PCB11 & 16-29 Feb 2004 & 37 & CTD, Multinet \\
\hline
\end{tabular}

Barents Sea. Thus, in periods of high abundance of $C$. finmarchicus in the NE Norwegian Sea, the abundance was also found to be high within the Barents Sea and vice versa. They also found that seawater temperature in the Barents Sea, indicating the extent of Atlantic water advection into the area, showed no clear relationship with the observed biomass of C. finmarchicus. Therefore, the project "Plankton Climatology in the Barents Sea" was initiated to seek the mechanisms governing the biomass variability of $C$. finmarchicus observed in the Barents Sea. Based on data from 2000-2002, Halvorsen et al. (2003) argued that deep-water, meso-scale eddies in the Lofoten Basin might provide favorable retention areas for the overwintering population of $C$. finmarchicus. Consequently, it is likely that these meso-scale physical features can influence the abundance and advection paths of the overwintering population the following spring and summer. As the project is terminated, time series data on the overwintering phase of copepods will be available from 2000-2006. This body of data will also contain deep water current measurements from moorings placed in the Lofoten Basin from November 2005 to March 2006. Based on the conceptual model proposed by Halvorsen et al. (2003), the current paper assess in more detail the distribution and dynamics of mainly $C$. finmarchicus, but also $C$. hyperboreus, compared to observed and modelled physical properties of the North Norwegian Sea in 2003 and 2004.

\section{Material and methods}

Field sampling was carried out in January and February, 2003-2004 with R/V "Jan Mayen" in the shelf slope and off shelf areas of the NE Norwegian Sea (Fig. 1, Table 1). Sampling locations were designed to cover the distribution of overwintering zooplankton. For each station temperature, and salinity was measured using a Seabird 911 ConductivityTemperature-Depth (CTD) profiler (Sea-Bird Electronics, inc., Washington, USA). For each profile, a water sample was collected at maximum depth for on-shore calibration of the conductivity sensor. Each profile was performed down to $10 \mathrm{~m}$ above the seabed or to a maximum depth of $1800 \mathrm{~m}$. Due to a broken conductivity sensor causing non-systematic drift in the measurements, salinity data were not available in January 2003. After each CTD profile, a MultiNet (Type

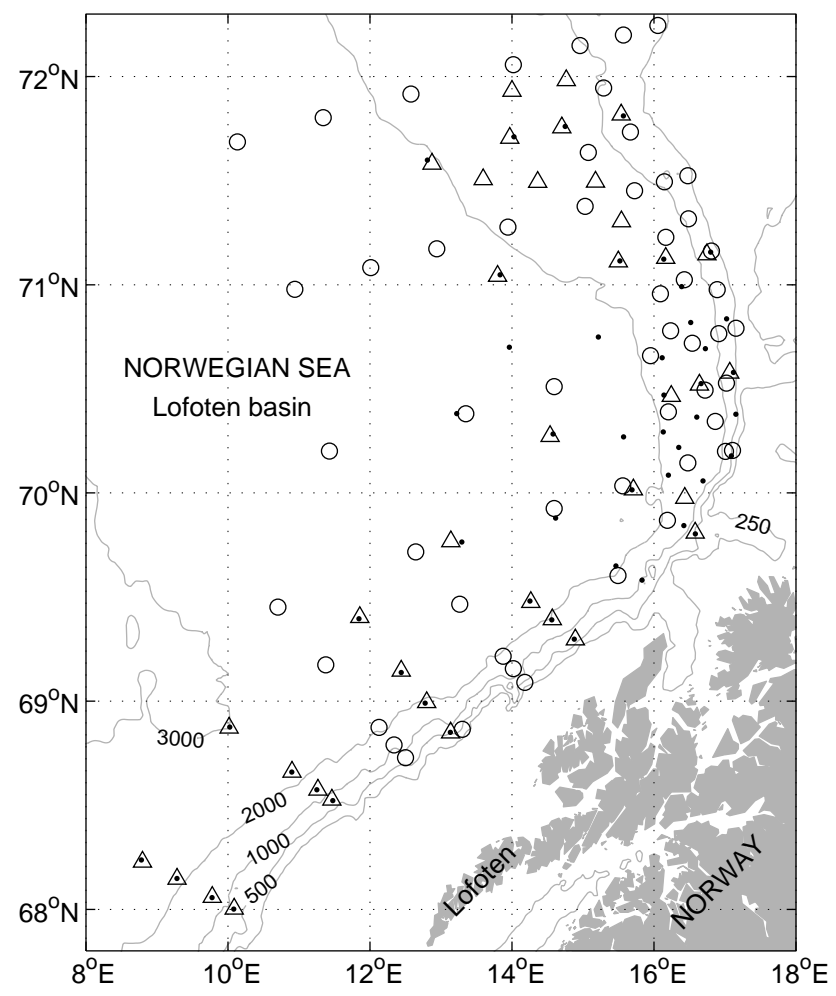

Fig. 1. The survey area is located in the northern parts of the Norwegian Sea, mainly west of the $500 \mathrm{~m}$ isobath. Sampling locations January 2003 (॰), January 2004 (•) and February 2004 ( $\triangle$ ) are given.

Midi; Hydro-Bios Apparatebau GmbH, Kiel-Holtenau, Germany) was lowered to $10-50 \mathrm{~m}$ above the seabed or to a maximum depth of $1800 \mathrm{~m}$ for collection of zooplankton. The MultiNet was equipped with five $180 \mu \mathrm{m}$ mesh-size plankton nets giving discrete sampling of five depth strata during ascent of each haul. A flowmeter inside the $0.25 \mathrm{~m}^{2}$ opening measured the water flowing through the nets. The MultiNet was hauled at a vertical speed of $0.5 \mathrm{~m} \mathrm{~s}^{-1}$. After retrieval, flow data were uploaded to the computer. For the surveys conducted in January 2003 and 2004, samples were collected at the depth intervals bottom, 500, 400, 300, $200,100,0 \mathrm{~m}$ at shallow stations. For the deep stations, one of the depth intervals was defined by the $0-2^{\circ} \mathrm{C}$ temperature range, hence depth intervals were bottom $/ 1800 \mathrm{~m}$, $1200 \mathrm{~m}, 0^{\circ} \mathrm{C}, 2^{\circ} \mathrm{C}, 200 \mathrm{~m}, 0 \mathrm{~m}$. For the survey conducted in February 2004, the sampling scheme was altered using fixed 300 and $600 \mathrm{~m}$ intervals giving bottom, 1200, 900, 600, 300, $0 \mathrm{~m}$ and bottom/1800, 1500, 1200, 900, 600, $0 \mathrm{~m}$ depth intervals. Upon retrieval zooplankton samples were collected from the cod-ends after flushing the nets. After processing (see below), all samples were preserved in hexamine buffered formaldehyde/seawater solution.

Prior to preservation, the biomass volume of each sample was measured after filtering out excessive water. Biomass 
Table 2. Physical criteria used to distinguish different water masses.

\begin{tabular}{lcc}
\hline Water domain & Temperature $\left({ }^{\circ} \mathrm{C}\right)$ & Salinity $(p s u)$ \\
\hline Coastal Water (CW) & $\geq 4$ & $<35$ \\
Atlantic Water (AW) & $>4$ & $\geq 35$ \\
Intermediate Water (IW) & $0-4$ & $<35$ \\
Deep Water (DW) & $\leq 0$ & $<35$ \\
\hline
\end{tabular}

data was used for underway mapping of the copepod biomass distribution. In order to gain more information in areas of high copepod biomass variability, additional sampling was performed in those areas after finishing the predefined stations. Counting was performed to stage specific abundance of Calanus finmarchicus, C. hyperboreus and C. glacialis in addition to one group containing other copepod taxa. C. finmarchicus and $C$. glacialis was distinguished based on prosome length, even though this method might be unreliable in some cases (Lindeque et al., 2006). Quantitative species composition within the group of other copepods was not examined further. Copepods smaller than $C$. finmarchicus stage CI were not counted. To map the horizontal distribution of $C$. finmarchicus in the survey area, depth averaged abundance at each station was fed into a meridional-zonal grid. Abundance in empty grid cells were estimated by interpolation (kriging, Surfer v6.01, Golden Software inc., Colorado, USA). Maps were made using M_Map (http://www2.ocgy.ubc.ca/ $\sim$ rich/map.html), and properties of seawater was calculated using the tools provided by Morgan (1994).

\section{Results}

\subsection{Bathymetry and hydrography}

The survey covered an area from the shelf break at a depth of $500 \mathrm{~m}$ to the deeper part of the Northern Norwegian Sea at maximum depth of $3000 \mathrm{~m}$ (Fig. 1). Bathymetry of the survey area is characterized by a steep shelf slope in the south with a drop from 500 to $2000 \mathrm{~m}$ over a distance of approximately $10 \mathrm{~km}$. As the Barents Sea opens to the east the shelf slope widens out and in the northern part of the survey area the distance between the 500 and $2000 \mathrm{~m}$ isobath is approximately $120 \mathrm{~km}$. Several small canyons intersects the shelf break forming channels from the continental shelf into the deep basin areas.

Four hydrographic regions were defined based on the physical properties of seawater found in the survey area (Table 2). In the surface, the relatively low saline Coastal Water (CW) overlay the warmer and saltier Atlantic Water (AW). A transition layer of Intermediate Water (IW) was defined between the AW and the cold Deep Water (DW). The depth of each of these water masses varied in space and time, and
Table 3. Relative mean areal abundance of the copepodites, female and male $C$. finmarchicus $\left(\mathrm{m}^{-2}\right)$ for all stations at each survey. Absolute numbers are given in parenthesis.

\begin{tabular}{|c|c|c|c|}
\hline Stage & Jan 2003 & Jan 2004 & Feb 2004 \\
\hline III & 0.00 & $(0)$ & (0) \\
\hline IV & $0.21 \quad(6568)$ & $0.13 \quad(3891)$ & $0.16 \quad(6229)$ \\
\hline V & $0.78(23747)$ & $0.85(25360)$ & $0.78(29801)$ \\
\hline$f$ & $0.02 \quad(470)$ & $0.02 \quad(558)$ & $0.03 \quad(1252)$ \\
\hline $\mathrm{m}$ & 0.00 & 0.00 & $0.02 \quad(796)$ \\
\hline Sum & $1.01(30853)$ & $1.00(29825)$ & $0.99(38078)$ \\
\hline
\end{tabular}

Table 4. Relative mean areal abundance of the copepodites, female and male $C$. hyperboreus $\left(\mathrm{m}^{-2}\right)$ for all stations at each survey. Absolute numbers are given in parenthesis.

\begin{tabular}{lrrrrrr}
\hline Stage & \multicolumn{2}{c}{ Jan 2003 } & \multicolumn{2}{c}{ Jan 2004 } & \multicolumn{2}{c}{ Feb 2004 } \\
\hline III & 0.17 & $(306)$ & 0.08 & $(120)$ & 0.12 & $(289)$ \\
IV & 0.25 & $(438)$ & 0.21 & $(297)$ & 0.25 & $(588)$ \\
V & 0.31 & $(550)$ & 0.29 & $(412)$ & 0.26 & $(618)$ \\
f & 0.21 & $(371)$ & 0.35 & $(488)$ & 0.30 & $(705)$ \\
m & 0.06 & $(107)$ & 0.07 & $(97)$ & 0.06 & $(138)$ \\
Sum & $1.00(1772)$ & \multicolumn{2}{l}{$1.00(1414)$} & 0.99 & $(2338)$ \\
\hline
\end{tabular}

there were transition zones of mixed water between them. However, in 2004 the 200-400 m layer of the survey area contained AW, while the DW predominated below $800 \mathrm{~m}$ (Fig. 2). In January, the average temperature of the AW was $1^{\circ} \mathrm{C}$ warmer in 2004 than in 2003. In 2004, more CW was found in the $0-100 \mathrm{~m}$ depth layer in January compared to February.

\subsection{Abundance of copepods}

Calanus finmarchicus dominated the meso-zooplankton community in terms of abundance and biomass. On average this species accounted for approximately $75 \%$ of the total abundance for all three surveys. C. hyperboreus occurred at approximately 5-10\% of the C. finmarchicus abundance. C. glacialis was found in 20 net samples during January 2003. In January and February 2004, C. glacialis was found in 2 and 1 net samples, respectively. For all occurrences of this species, the abundance was very low $(0.01-$ $0.33 \mathrm{~m}^{-3}$ ). Other copepods (i.e. Metridia spp., Pareuchaeta spp. and Gaidius spp.) made up approximately $20 \%$ of the total abundance, but less so in terms of biomass. In the following, C. finmarchicus and C. hyperboreus will be dealt with in more detail.

The average abundance of $C$. finmarchicus in the survey area was in in the range $30000-38000 \mathrm{~m}^{-2}$ (Table 3). Distribution of developmental stages was on average 17:80:2:1 for copepodite stages IV, V, female and male, respectively. C. hyperboreus was present at and average abundance of 

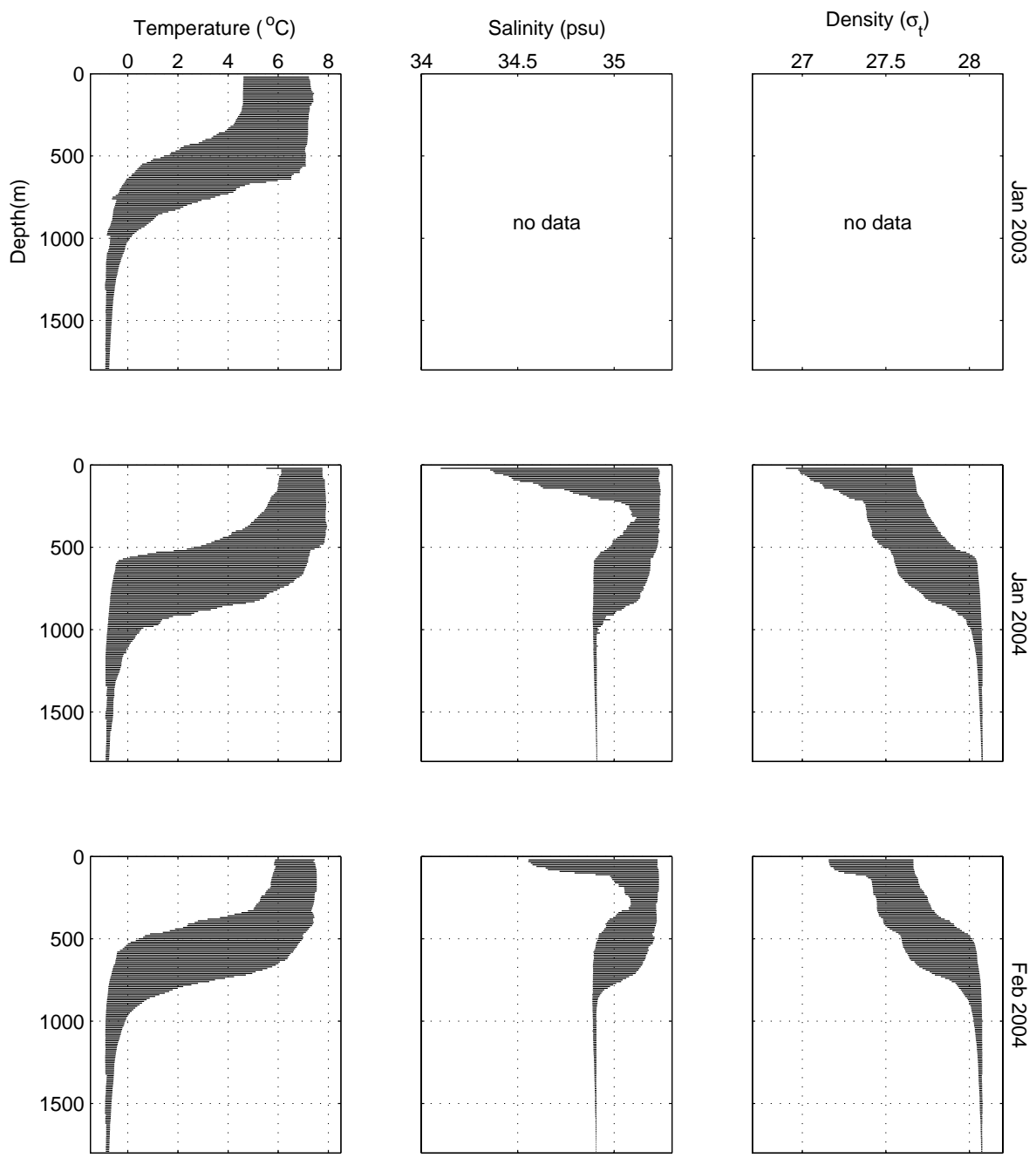

Fig. 2. Minimum and maximum values of seawater temperature, salinity and density $\left(\sigma_{t}=\mathrm{kg} \mathrm{m}^{-3}-1000\right)$ at atmospheric pressure for each survey. Data from 2003 are given in the upper panels, while data from 2004 are shown in the panels below. Salinity and hence density data were not available for 2003 .

$1400-2300 \mathrm{~m}^{-2}$ (Table 4). Developmental stage distribution was approximately 2:4:5:5:1 for copepodites III, IV, V, female and male, respectively.

\subsection{Vertical distribution of copepods}

In January 2003 and 2004, the abundance of $C$. finmarchicus peaked at $600-1200 \mathrm{~m}$ depth, while the highest abundance of $C$. hyperboreus was found below $1200 \mathrm{~m}$ (Fig. 3), and in January 2003, the highest abundance was found in the depth range 1500-1800 m indicating that part of the $C$. hyperboreus population resided below the depth of sampling. For the other copepods group, abundance was highest above $1200 \mathrm{~m}$.

A shift in the depth distribution for both $C$. finmarchicus and $C$. hyperboreus indicated that upward migration took place from January to February 2004 (Fig. 4). For both species, the abundance peak shifted approximately one depth bin, i.e. $300 \mathrm{~m}$, over a period of one month. Hence, the vertical upward migration speed was of the order of $10 \mathrm{~m} \mathrm{~d}^{-1}$.

\subsection{Horizontal distribution of copepods}

Due to the dominance of $C$. finmarchicus, this species was used for the horizontal mapping of copepod abundance in the survey area. In general, high concentrations were found in a band adjacent to the shelf break west of the $1000 \mathrm{~m}$ isobath (Fig. 5), but location of high abundance patches along this band shifted between years (January 2003 and 2004) and within years (January and February 2004). Hence, the horizontal position of overwintering copepods was indeed dynamic. However, adjacent to the $1000 \mathrm{~m}$ isobath at $70-72^{\circ} \mathrm{N}$ the abundance was always intermediate or high. Both in January 2003 and 2004, maximum abundances were found in 

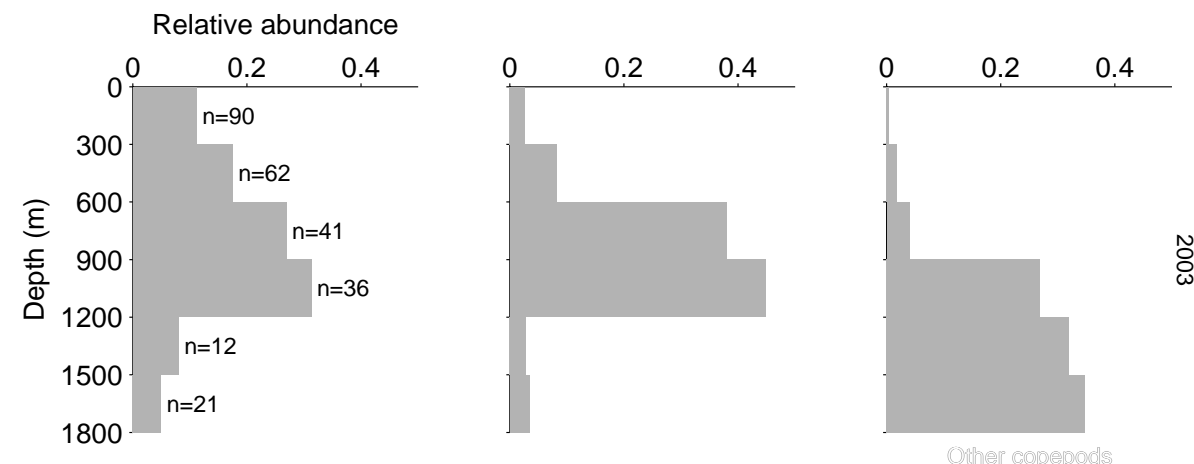

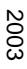
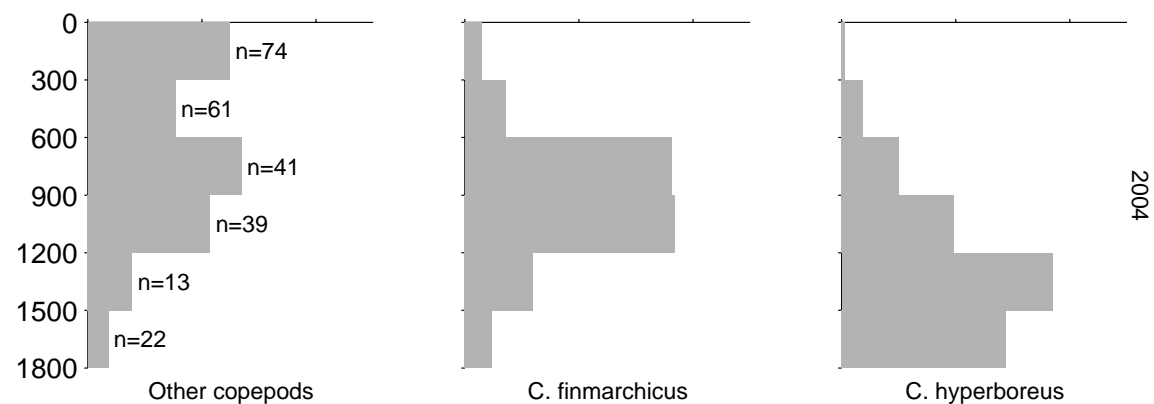

Fig. 3. Relative abundance for each copepod group in $300 \mathrm{~m}$ depth bins during the surveys in January 2003 (upper panels) and 2004 . Number of samples in each depth bin are given in the left panels.
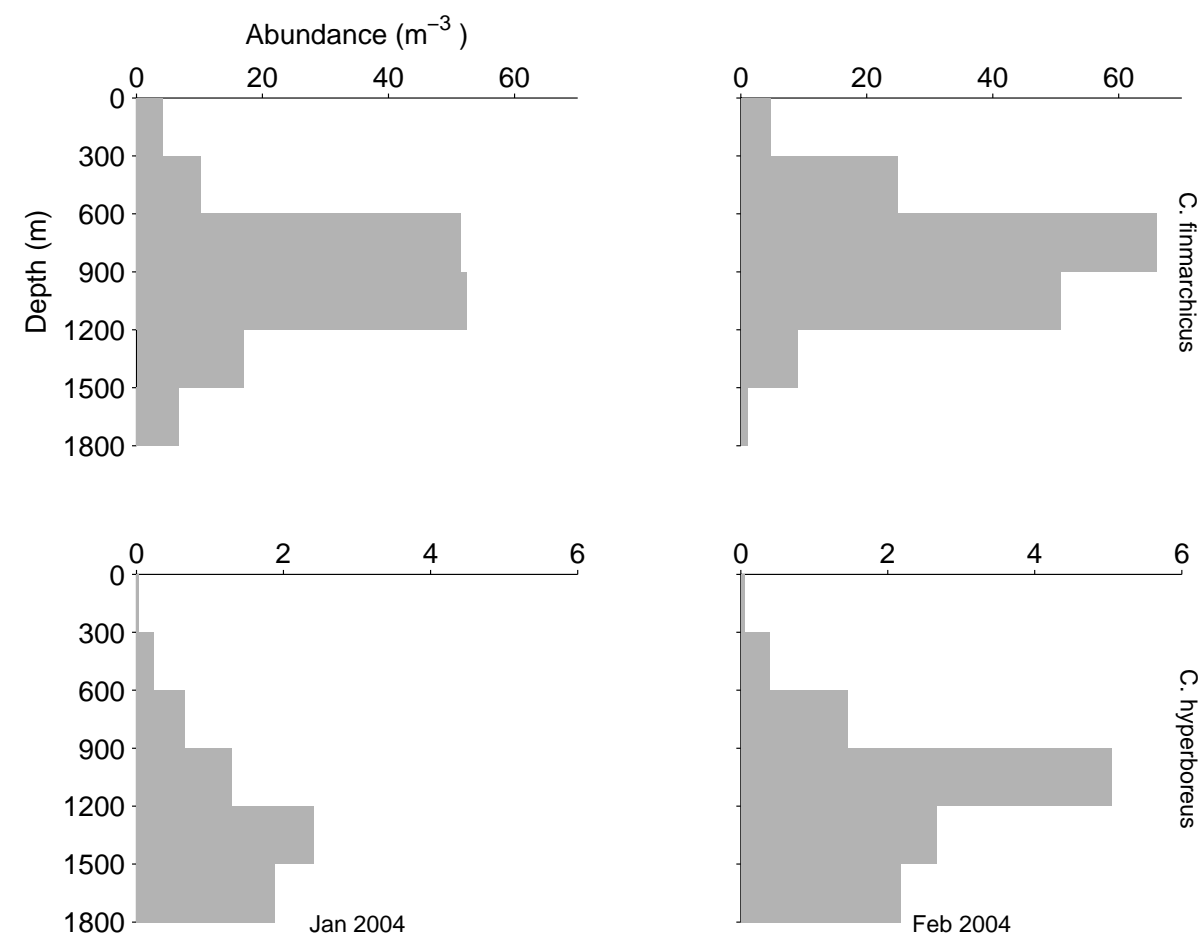

Fig. 4. Vertical distributed abundance of $C$. finmarchicus (upper panels) and C. hyperboreus during January (left panels) and February 2004. See also Fig. 3. 
Table 5. Mean abundance of $C$. finmarchicus and $C$. hyperboreus $\left(\mathrm{m}^{-3}\right)$ in different water masses as defined in Table 2. Relative numbers are given in parenthesis. Data from January 2004.

\begin{tabular}{lrccc}
\hline Water domain & \multicolumn{2}{c}{ C. finmarchicus } & \multicolumn{2}{c}{ C. hyperboreus } \\
\hline Coastal Water (CW) & 5.18 & $(0.05)$ & 0.08 & $(0.03)$ \\
Atlantic Water (AW) & 7.41 & $(0.07)$ & 0.14 & $(0.05)$ \\
Intermediate Water (IW) & 61.92 & $(0.60)$ & 0.76 & $(0.28)$ \\
Deep Water (DW) & 28.86 & $(0.28)$ & 1.70 & $(0.63)$ \\
\hline
\end{tabular}

this area. In February 2004, the maximum abundance was found in the southern part of the survey area at $68^{\circ} \mathrm{N}$. The western parts of the survey area was recognized by intermediate or low abundance of $C$. finmarchicus during all three surveys.

\subsection{Hydrographic distribution of copepods}

Results from the depth distribution (Fig. 3) indicated that the different copepod species occupied different habitats. Using the water domains as defined in Table 2, the segregation between $C$. finmarchicus and $C$. hyperboreus was more pronounced. The average abundance of $C$. hyperboreus in Deep Water (DW) was more than twice of that found in the Intermediate Water (IW, Table 5).

For $C$. finmarchicus the average abundance in the IW was $62 \mathrm{~m}^{-3}$ and $29 \mathrm{~m}^{-3}$ in the DW domain. The majority of the C. finmarchicus population was found at temperatures below $2^{\circ} \mathrm{C}$ in January 2004, while in February 2004, C. finmarchicus was more evenly distributed among the DW, IW and AW domains (Fig. 6).

\section{Discussion}

During January and February 2003 and 2004, the distribution of overwintering copepods was measured in the Lofoten Basin, an off shelf, oceanic region of the North Norwegian Sea. In 2003, the survey area seemed to have been influenced by colder water masses than in 2004. The difference in average temperature was approximately $1^{\circ} \mathrm{C}$ throughout the top $500 \mathrm{~m}$. Even though found at low numbers, the arctic species $C$. glacialis was found in 20 samples during January 2003, but only in two samples during January 2004, further indicating that 2003 was the colder year of the two.

C. finmarchicus was the dominant species making up $75 \%$ of the total abundance of meso zooplankton. C. hyperboreus occurred at approximately $10 \%$ of the $C$. finmarchicus abundance. C. finmarchicus was also dominant during 20002002 (unpublished data, but see also Halvorsen et al., 2003). Hence, this species is indeed a robust indicator of the overall biomass of copepods in the Northern Norwegian Sea. C. finmarchicus was mainly found as copepodite stage V (78$85 \%)$, but also as stage IV (13-21\%). Adult females and males were present at $2-3 \%$ and $0-2 \%$, respectively. The distribution of developmental stages was very similar to that found in waters around Iceland during winter (Gislason and Astthorsson, 2000). However, data from the southern Norwegian Sea during winter 1996 (Heath et al., 2000) showed that the portion of stage IV was more important and even dominant at some depths making up more than $60 \%$ of the C. finmarchicus abundance. Table 3 indicate that the ratio of adult males increased from January to February 2004. This was probably due to ontogenetic development within the population rather than transportation of males into the survey area. For C. hyperboreus, abundance was more evenly distributed among the copepodite stages, but dominated by stages IV, $\mathrm{V}$ and adult females, reflecting the two year life cycle of this species. This is in accordance with data from the Irminger Sea during winter where stage IV and V made up 50-60\% and adult females 30-40\% (Gislason, 2003, his Fig. 9).

The overall depth distribution (Figs. 3 and 4) showed that the population of $C$. finmarchicus resided above that of $C$. hyperboreus indicating different habitat preferences between these two species. Further, the abundance peak of $C$. hyperboreus was close to $1800 \mathrm{~m}$ suggesting that the maximum sampling depth was insufficient to cover the overwintering population of this species. The fact that the average abundance of $C$. hyperboreus doubled in the survey area from January to February 2004 (Table 4) and that during December, Gislason (2003) found parts of the C. hyperboreus below $1800 \mathrm{~m}$ in the Irminger Sea, indicated that deeper sampling should be used for this species. From the depth distribution it was also possible to conclude that an upward displacement had taken place between January and February 2004. The magnitude of displacement was approximately $300 \mathrm{~m}$, providing a speed of $10 \mathrm{~m} \mathrm{~d}^{-1}$ for both $C$. finmarchicus and $C$. hyperboreus. According to data compiled by Hirche (1996), the termination of the diapause in C. finmarchicus is to take place at the end of January with a ascent phase from February to March. To meet this scheme, the upward migration speed will have to increase over the ascent period. Since the body lipid of $C$. finmarchicus is more compressible than seawater and due to thermal expansion of lipids, an increased ascent speed approaching the surface due to buoyancy forces, is likely (Visser and Jónasdóttir, 1999; Campbell and Dower, 2003).

For 2003 and 2004, some general features in the distribution of $C$. finmarchicus should be noted: 1) high concentrations occurred in a band adjacent to the shelf break, 2) to the west of this band concentration was low or intermediate and 3) in the north eastern part of the survey area concentrations were always intermediate or high. Even though not conclusive, similar pattern were observed by Halvorsen et al. (2003) during January 2000-2002. They argued that aggregation and dispersal of $C$. finmarchicus occurred as a combined effect of late summer and autumn downward migration and meso scale eddy activity in the area resulting in 

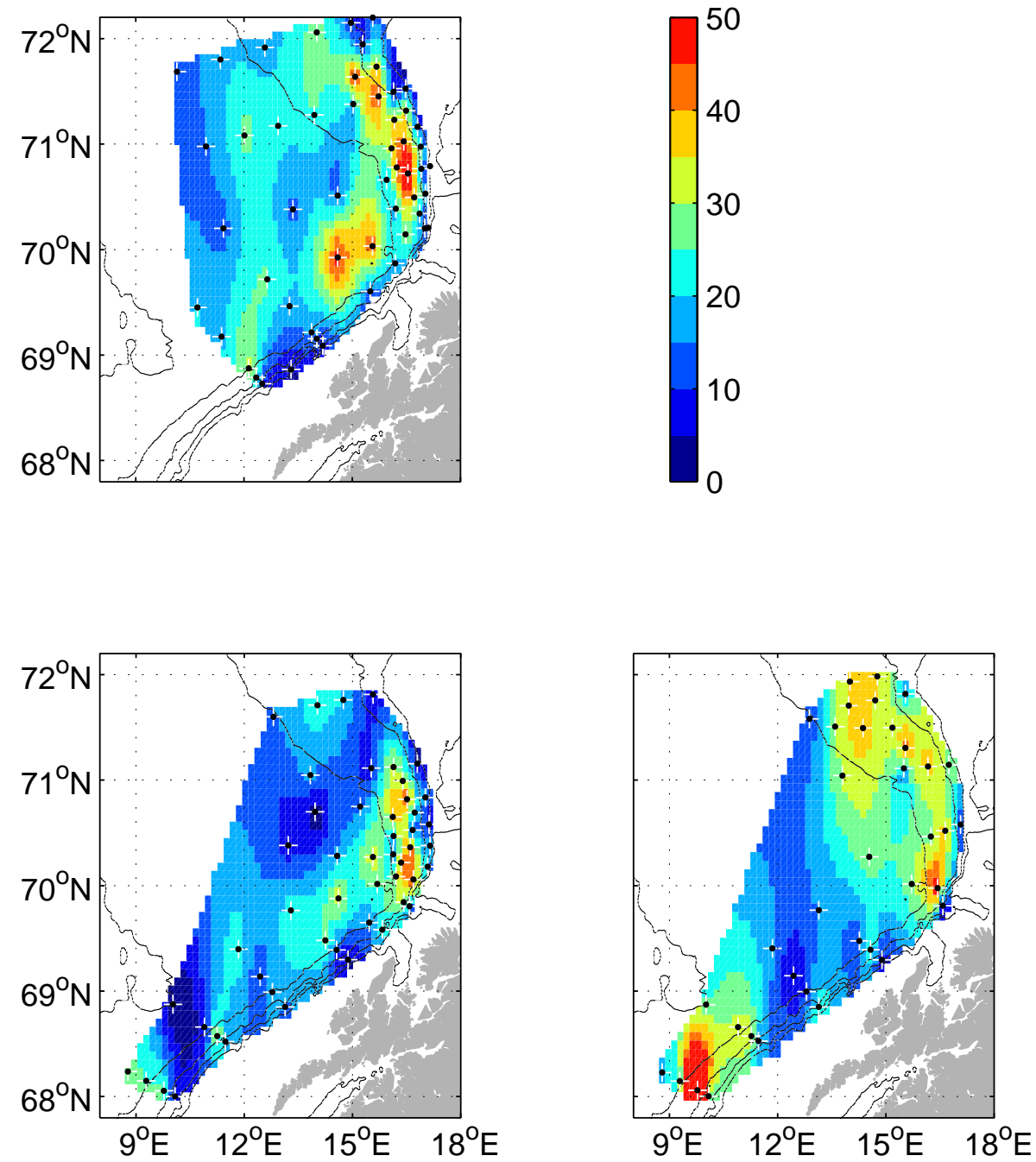

Fig. 5. Map interpolated from average abundance of $C$. finmarchicus $\left(\mathrm{m}^{-3}\right)$ at each station $(\bullet /+)$ during the surveys in January 2003 (upper panel) and January and February 2004 (lower left and right panels, respectively).

a meso scale patchy distribution of the overwintering population. For the water column above the continental margin, such eddy activity has been shown to be a prominent feature (Poulain et al., 1996; Orvik and Niiler, 2002), but in the deeper part of the water column there is a lack of empirical data.

For each station, the MultiNet allowed for sampling in five discrete depth intervals from the bottom/1800 $\mathrm{m}$ to the surface. Hence, the vertical resolution must be regarded as crude. This must be taken into account when linking the distribution of copepods to the CTD data averaged over the depth interval of each net. During the surveys in January 2003 and 2004 sampling was not performed independently on the hydrographic properties since one of the depth intervals was fixed to the $0-2^{\circ} \mathrm{C}$ temperature range. However, from the abundance of $C$. finmarchicus it was clear that the population was found below $2^{\circ} \mathrm{C}$ during January (Fig. 6), similar to that reported by Halvorsen et al. (2003) for 2000 2002. It was also evident that this pattern was changing during February 2004 as the overwintering population had started the ascent. The temperature range previously reported for overwintering C. finmarchicus in the Nordic Seas is broad. During November and December C. finmarchicus was mainly found at $3-8^{\circ} \mathrm{C}$ in the Iceland Basin and at 3$6^{\circ} \mathrm{C}$ in the Irminger Basin (Gislason and Astthorsson, 2000). Similar, high temperatures was also reported from the Norwegian Trench and the Rockall Basin (Heath et al., 2004). At the cold end, the population of $C$. finmarchicus north of the Iceland-Scotland ridge and in the Faroe-Shetland Channel was found from -0.5 to $0.5^{\circ} \mathrm{C}$ (Heath et al., 2004).

It is likely that the variability in temperature, at which an overwintering populations is found, is governed by seabed 

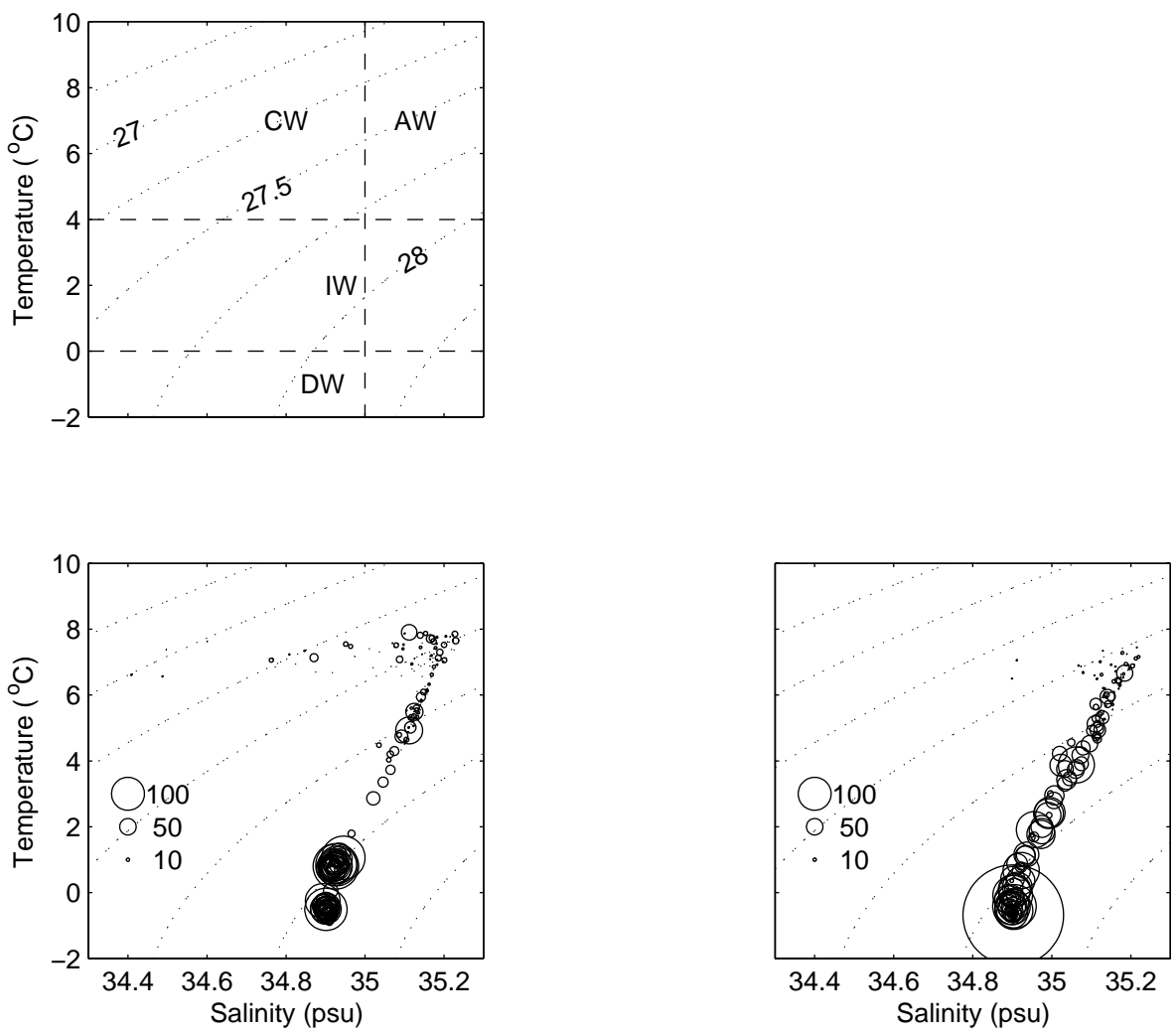

Fig. 6. Hydrographic distribution and abundance $\left(\mathrm{m}^{-3}\right)$ of $C$. finmarchicus for each sample in January (lower left panel) and February (right panel). Different hydrographic domains (Table 2 ) and density $\left(\sigma_{t}\right)$ at atmospheric pressure are given in the top panel.

depth and/or in situ seawater-copepod density contrast, rather than different temperature preferences among local populations of $C$. finmarchicus in the North Atlantic Ocean. Where the seabed does not represent a boundary for downward migration, diapause is expected to take place close to neutral buoyancy (Visser and Jónasdóttir, 1999), even though this state might not represent a fully stable condition (Campbell and Dower, 2003). During January, most $C$. finmarchicus IV, $\mathrm{V}$ and females were found at a mean in situ water density of approximately $1032 \mathrm{~kg} \mathrm{~m}^{-3}$, and $C$. finmarchicus males at approximately $1029.5 \mathrm{~kg} \mathrm{~m}^{-3}$ (Fig. 7).

Assuming a state of hibernation and hence neutral buoyancy, females were slightly more dense than stage IV copepodites, which in turn were slightly more dense than stage $\mathrm{V}$ copepodites. The same pattern was found in a lab experiment by Knutsen et al. (2001), but at higher levels of density. There were no data to support the density found for males. One month later, as the overwintering phase was terminated, only females had moved to waters of lower density. For the other stages, changes in the density of the water in which they were found were minor. Males are believed to be the first to enter the surface in spring (Hirche, 1996, and references therein). However, during February 2004 males were found at higher in situ water density than one month ear- lier, indicating that upward migration of males started later than for females. The moult into males that probably occurred from January to February (see above), would also have contributed to the increased in situ density of water were most males were found. In the Faroe-Shetland Channel, the first animals that emerged from the overwintering habitat in February moulted into males and remained at 300$500 \mathrm{~m}$ depth as females ascended towards the surface later in the season (Heath, 1999). Both in the Irminger Basin and the Iceland Basin, Gislason and Astthorsson (2000) found that males resided deeper than females in April. During this period, only parts of the population had entered surface waters (Gislason and Astthorsson, 2000).

The density of copepods is determined by the relative composition of lipid, water, protein and chitin (Visser and Jónasdóttir, 1999), e.g. for copepods the diapause habitat will be a function of development stage and feeding history. With regard to horizontal displacement during winter and spring, the variability of density among species and developmental stages within species, will therefore cause variability in the spatial trajectories of the population. It has been suggested that a variation of lipid content among $C$. finmarchicus in the North Atlantic can represent an adaption for retention within the circulation domains of the different populations (Heath 


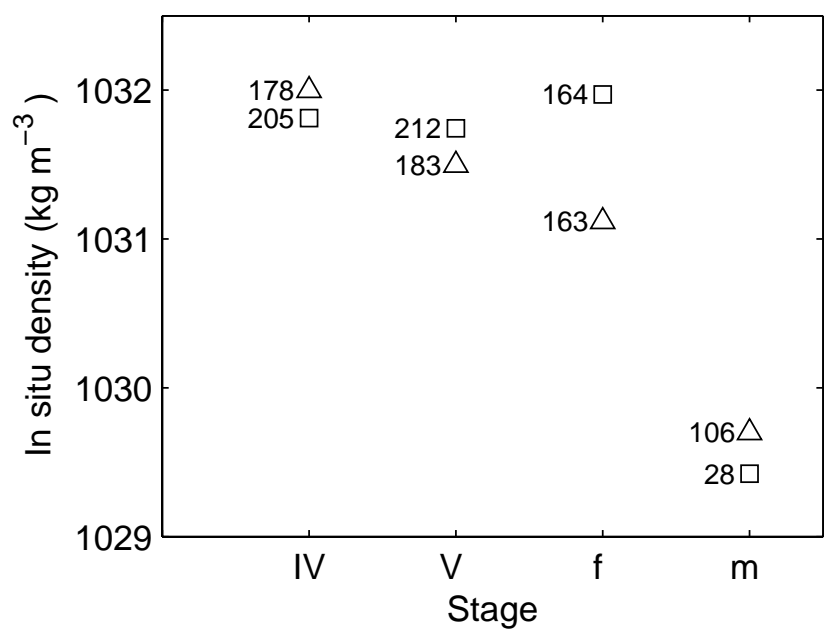

Fig. 7. Indications of in situ seawater density preferences among the copepodite stages of $C$. finmarchicus during January $(\square)$ and February $(\triangle)$ 2004. Data represents the mean in situ seawater density weighted by the abundance of $C$. finmarchicus $\left(\mathrm{m}^{-3}\right)$ for each sample. The number of samples are given to the left of each data point.

et al., 2004; Irigoien, 2004). For the C. finmarchicus population in the Lofoten Basin, advection to the Norwegian shelf, the Barents Sea and north towards the polar basin during spring and summer will represent an effective sink. However, parts of the population will be drained back into the Lofoten Basin from shelf areas and the Barents Sea as the advanced copepodite stages descend during late summer and autumn. It is not known if this is sufficient to sustain a persistent population in the Lofoten Basin system, but it is likely that the Lofoten Basin represents a retention area for copepods advected to the area both during autumn and winter.

Simulated deep water current data from the hydrodynamical model SINMOD (for a detailed description of SINMOD, see Moseidjord et al., 1999; Slagstad et al., 1999; Slagstad and McClimans, 2005) suggests that the observed dynamics in distribution of the overwintering population of C. finmarchicus is caused by interaction between bottom topography and large scale ocean circulation with the North Atlantic Current (NAC) as the major driving force, and episodic events governed by local and distant atmosphere and ocean forcing acting on the target area altering this process (Slagstad and Tande, in review). South of $70^{\circ} \mathrm{N}$, the NAC piles up water towards the narrow shelf break and main land of Norway causing a steep surface slope towards the coast. The pressure gradient in most of the water column will be dominated by the surface slope and the currents tend to be barotropic causing the water below the NAC to move north, parallel to the shelf slope. North of $70^{\circ} \mathrm{N}$ the Barents Sea opens up to the east and the shelf slope is less steep. Due to a decrease of the Taylor column thicknesses there will be an increase of anticyclonic vorticity causing the northwards flow-

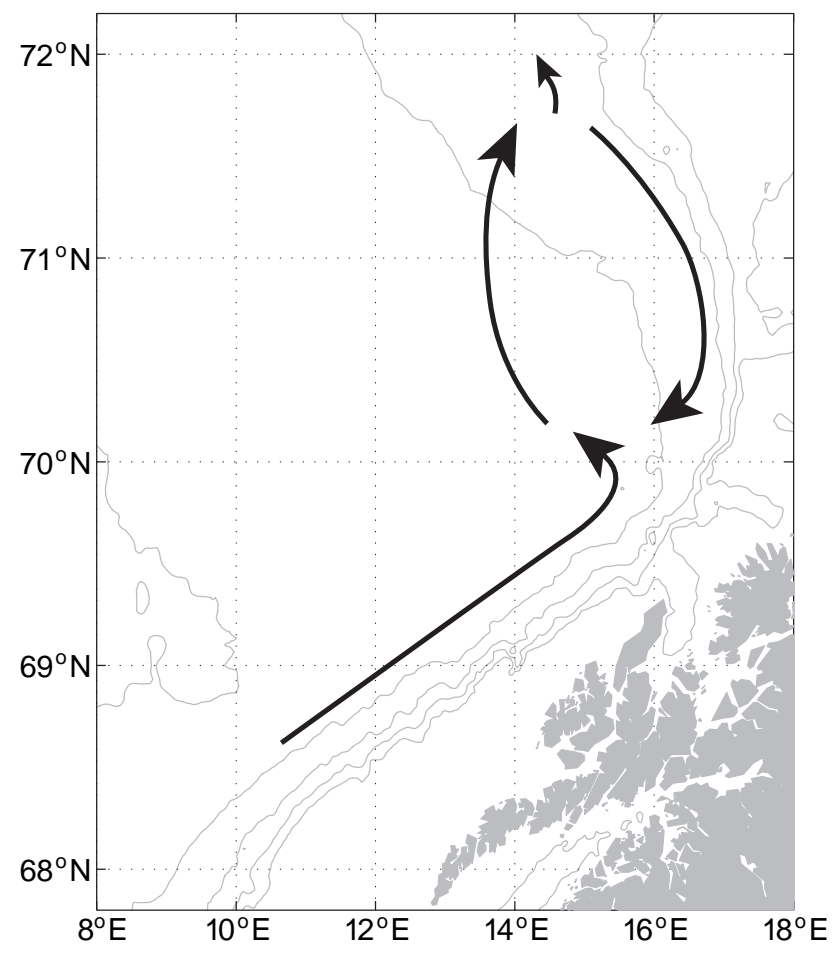

Fig. 8. Overall pathways of the water masses holding the overwintering population of copepods as suggested by the SINMOD current simulations.

ing water to deflect westward. The pressure gradient across the shelf break is less dominated by the sea surface slope and horizontal pressure gradients become more important in deep water. The result is an anticyclonic eddy situated outside the shelf north of $70^{\circ} \mathrm{N}$ capable of retaining overwintering copepods (Fig. 8).

During episodic strengthening of the NAC, water masses below the NAC is effectively transported from the south towards the area of the eddy. From January to February 2004, an area of low biomass seemed to have shifted northwards while an area of very high biomass concentration was observed in the southernmost part of the area. This could have been caused by such an episodic strengthening of the NAC and hence increased flow of deep water towards the northeast. As data from the current measurements in the Lofoten Basin over the period from November 2005 to March 2006 become available, the above model results can be evaluated.

Acknowledgements. Technical support during the cruises was provided by B. Vaaja, J.-T. Eilertsen, R. Buvang, F. Tonning, O. Nordgård and K. Lydersen. They kept admirable high spirit in spite of rather unpleasant weather conditions that often occur in the open ocean during winter. The authors also wish to thank the crew on R/V "Jan Mayen". This project was supported by the Research council of Norway, grant number 153070/120.

Edited by: K. Döös 


\section{References}

Backhaus, J. O., Harms, I. H., Krause, M., and Heath, M. R.: An hypothesis concerning the space-time succession of Calanus finmarchicus in the northern North Sea, ICES J. Mar. Sci., 51, 169180, 1994.

Bryant, A. D., Hainbucher, D., and Heath, M.: Basin-scale advection and population persistence of Calanus finmarchicus, Fisheries Oceanogr., 7, 235-244, 1998.

Campbell, R. W. and Dower, J. F.: Role of lipids in the maintenance of neutral buoyancy by zooplankton, Mar. Ecology-Progress Series, 263, 93-99, 2003.

Gislason, A.: Life-cycle strategies and seasonal migrations of oceanic copepods in the Irminger Sea, Hydrobiologia, 503, 195209, 2003.

Gislason, A. and Astthorsson, O. S.: Winter distribution, ontogenetic migration, and rates of egg production of Calanus finmarchicus southwest of Iceland, ICES J. Mar. Sci., 57, 1727$1739,2000$.

Halvorsen, E., Tande, K. S., Edvardsen, A., Slagstad, D., and Pedersen, O. P.: Habitat selection of overwintering Calanus finmarchicus in the NE Norwegian Sea and shelf waters off Northern Norway in 2000-02, Fisheries Oceanogr., 12, 339-351, 2003.

Heath, M.: The ascent migration of Calanus finmarchicus from the overwintering depths in the Faroe-Shetland Channel, Fisheries Oceanogr., 8, 84-99, 1999.

Heath, M., Backhaus, J., Richardson, K., McKenzie, E., Slagstad, D., Beare, D., Dunn, J., Fraser, J., Gallego, A., Hainbucher, D., Hay, S., Jónasdóttir, S., Madden, H., Mardaljevic, J., and Schacht, A.: Climate fluctuations and the spring invasion of the North Sea by Calanus finmarchicus, Fisheries Oceanogr., 8, 163176, 1999.

Heath, M. R., Fraser, J. G., Gislason, A., Hay, S. J., Jónasdóttir, S. H., and Richardson, K.: Winter distribution of Calanus finmarchicus in the Northeast Atlantic, ICES J. Mar. Sci., 57, 1628$1635,2000$.

Heath, M. R., Boyle, P. R., Gislason, A., Gurney, W. S. C., Hay, S. J., Head, E. J. H., Holmes, S., Ingvarsdóttir, A., Jónasdóttir, S. H., Lindeque, P., Pollard, R. T., Rasmussen, J., Richards, K., Richardson, K., Smerdon, G., and Speirs, D.: Comparative ecology of over-wintering Calanus finmarchicus in the northern North Atlantic, and implications for life-cycle patterns, ICES J. Mar. Sci., 61, 698-708, 2004.

Hirche, H. J.: Distribution of dominant calanoid copepod species in the Greenland Sea during late fall, Polar Biology, 11, 351-362, 1991

Hirche, H. J.: Diapause in the marine copepod, Calanus finmarchicus - A review, Ophelia, 44, 129-143, 1996.

Irigoien, X.: Some ideas about the role of lipids in the life cycle of Calanus finmarchicus, J. Plankton Res., 26, 259-263, 2004.

Kaartvedt, S.: Habitat preference during overwintering and timing of seasonal vertical migration of Calanus finmarchicus, Ophelia, 44, 145-156, 1996.
Knutsen, T., Melle, W., and Calise, L.: Determining the mass density of marine copepods and their eggs with a critical focus on some of the previously used methods, J. Plankton Res., 23, 859873, 2001.

Krause, M. and Radach, G.: On the relations of vertical-distribution, diurnal migration and nutritional state of herbivorous zooplankton in the northern North Sea during FLEX 1976, Internationale Revue Der Gesamten Hydrobiologie, 74, 371-417, 1989.

Lindeque, P. K., Hay, S. J., Heath, M. R., Ingvarsdottir, A., Rasmussen, J., Smerdon, G. R., and Waniek, J. J.: Integrating conventional microscopy and molecular analysis to analyse the abundance and distribution of four Calanus congeners in the North Atlantic, J. Plankton Res., 28, 221-238, 2006.

Morgan, P. P.: SEAWATER: A Library of MATLAB Computational Routines for the Properties of Sea Water, Tech. Rep. 222, CSIRO Mar. Laboratories, 1994.

Moseidjord, H., Svendsen, H., and Slagstad, D.: Sensitivity studies of circulation and ocean-shelf exchange off northern Norway, Sarsia, 84, 191-198, 1999.

Orvik, K. A. and Niiler, P.: Major pathways of Atlantic water in the northern North Atlantic and Nordic Seas toward Arctic, Geophys. Res. Lett., 29, 2002.

Østvedt, O.-J.: Zooplankton investigations from weather ship M in the Norwegian Sea, 1948-49, vol. 40 of Hvalrådets skrifter, Dybwad, 1955.

Planque, B. and Batten, S. D.: Calanus finmarchicus in the North Atlantic: the year of Calanus in the context of interdecadal change, ICES J. Mar. Sci., 57, 1528-1535, 2000.

Poulain, P. M., Warn-Varnas, A., and Niiler, P. P.: Near-surface circulation of the Nordic seas as measured by Lagrangian drifters, J. Geophys. Res., 101, 18 237-18 258, 1996.

Slagstad, D. and McClimans, T. A.: Modeling the ecosystem dynamics of the Barents Sea including the marginal ice zone: I. Physical and chemical oceanography, J. Mar. Syst., 58, 1-18, 2005.

Slagstad, D., Tande, K. S., and Wassmann, P.: Modelled carbon fluxes as validated by field data on the north Norwegian shelf during the productive period in 1994, Sarsia, 84, 303-317, 1999.

Tande, K. S. and Miller, C. B.: Population dynamics of Calanus in the North Atlantic: results from the trans-Atlantic study of Calanus finmarchicus, ICES J. Mar. Sci., 57, 1527-1527, 2000.

Tande, K. S., Drobysheva, S., Nesterova, V., Nilssen, E. M., Edvardsen, A., and Tereschenko, V.: Patterns in the variations of copepod spring and summer abundance in the northeastern Norwegian Sea and the Barents Sea in cold and warm years during the 1980s and 1990s, ICES J. Mar. Sci., 57, 1581-1591, 2000.

Visser, A. and Jónasdóttir, S.: Lipids, buoyancy and the seasonal vertical migration of Calanus finmarchicus, Fisheries Oceanogr., 8, 100-106, 1999. 